Tips om medisinsk litteratur, andre bøker, filmer og elektroniske medier som bør anmeldes, sendes tidsskriftet@legeforeningen.no

\section{Lærebok som burde vært mye bedre}

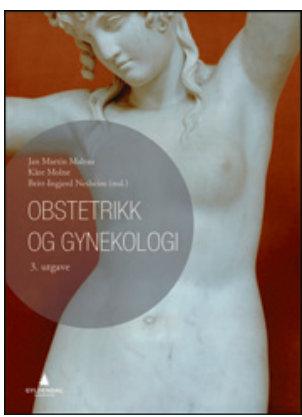

Jan Martin Maltau, Kåre Molne,

Britt-Ingjerd Nesheim

Obstetrikk og gynekologi

3. utg. 399 s, tab, ill. Oslo: Gyldendal

Akademisk, 2015. Pris NOK 795

ISBN 978-82-05-45234-3

Dette er tredje utgave av læreboken i obstetrikk og gynekologi som brukes av de fleste norske medisinstudenter. Ifølge forordet skal innholdet være oppdatert i forhold til forrige utgave som kom i 2010, men det er ikke foretatt grunnleggende endringer. Boken bygger på de to bøkene Obstetrikk fra 1987 og Gynekologi fra 1990 som ble samlet til én bok i 2004, og som i alle år har hatt de samme redaktørene. Dette er et svært viktig læreverk innenfor norsk medisinsk faglitteratur, som har preget tusenvis av norske leger gjennom årene.

Nye forfattere er kommet til, i alt er det 40 bidragsytere. De færreste er klinisk aktive. De fleste er pensjonister eller blir det i nær fremtid. Å bruke de siste årene til å formidle sin kunnskap til neste generasjon er livets sirkel, men faren er at disse overleveringene får et alderdommelig preg, en problemstilling som ble påpekt allerede i Tidsskriftets anmeldelse av førsteutgaven i 2005.

Som i de forrige utgavene varierer kapitlene mye i disposisjon, layout og leservennlighet. Noen kapitler har mye sammenhengende tekst, mens andre kapitler er godt utstyrt med tekstbokser og punkter, fargebilder og skjematiske illustrasjoner. Det er også stor variasjon i detaljeringsgraden, for eksempel er det $\mathrm{i}$ kapitlet om gynekologisk undersøkelse funnet plass til inventarliste for undersøkelsesrom og en liste over aktuelle rekvisisjonsskjemaer. Det styrker det alderdommelige preget, for elektronisk rekvisisjon av prøver er faktisk vanlig. Andre kapitler er ganske summariske, for eksempel er det velskrevne kapitlet om gynekologisk kreft svært kompakt med bare 13 sider.

Fortsatt er det en rekke inkonsistenser mellom kapitlene/kapittelforfatterne, for eksempel brukes begrepene vaginalcytologi og cervixcytologi om hverandre. Uttrykkene grov og lett dysplasi er nevnt et par steder, begrep som tilhører en forlatt cytologisk klassifisering. Folsyre omtales også som folat og folinsyre, til tross for at dette ble påpekt $\mathrm{i}$ Tidsskriftets anmeldelse av forrige utgave i 2010 .

Forordet til 2. utgave er tatt inn. Her skrev (de pensjonerte) redaktørene at litteraturlister og angivelse av utfyllende lesing ikke hører hjemme i en lærebok for studenter. Det er vanskelig å finne argumenter for dette, og redaktørene forsøker heller ikke. Moderne lærebøker bør bekjenne seg til kunnskapsbasert medisin, det bør oppgis sentrale referanser - fortrinnsvis til kunnskapsanalyser der dette finnes - og fremstillingen i teksten bør klargjøre hvor kunnskapsgrensene går. Følger man ikke dette prinsippet, blir lærebøkene kokebøker, avstanden mellom klinisk medisin og forskning $ø$ ker, og profesjonsstudiets yrkesskolepreg forsterkes. Noen av forfatterne har likevel trosset redaktørenes prinsipp og oppgir både sentrale referanser og utfyllende lesing. Prisverdig!

Etter hvert kapittel kommer en oversikt over personnavnene i teksten, med korte biografier. De som synes det er spennende å se hvem som skjuler seg under navn som Küstner, Fick og Fitz-Hugh, får stilt sin kunnskapstørst. Men de som er interessert i faglig fordypning, får i forordet beskjed om at de kan lete videre i fagbibliotek eller på internett. Denne prioriteringen bør diskuteres.

Bidragsyterne dekker utvilsomt de fleste temaene som studentene bør kjenne til, og denne utgaven blir sikkert like populær som de tid- ligere utgavene. De som underviser, må supplere når det gjelder temaer som mangler, eller ting som bør korrigeres. Det gjelder for eksempel non-invasiv prenatal diagnostikk, som er i ferd med å revolusjonere fosterdiagnostikken, men her står det bare at dette ikke brukes i Norge. Fosterreduksjon nevnes ikke, heller ikke hjemmeabort som er en vanlig brukt metode ved provosert abort. Vaginal ultralyd som har revolusjonert gynekologisk diagnostikk, er bare tilgodesett med fem linjer i kapitlet om gynekologisk undersøkelse. Praktisk utførelse av endometriebiopsi må studentene kjenne til, men dette er ikke omtalt. Terminberegning, som har vært og er et offentlig diskusjonstema, er uhyre kortfattet omtalt, og moderne metoder nevnes ikke. Økningen i tvillingsvangerskap fra 1985 tilskrives assistert befruktning, noe som er en forenkling. Aldersøkningen i populasjonen av fødende er en viktig faktor som bidrar, men som ikke nevnes. Dermed går studentene glipp av et viktig poeng.

Fødsel omtales i to kapitler, Den normale fødselen og Avvikende fødsler, komplikasjoner og intervensjoner. Setefødsler og tvillingfødsler omtales i det siste kapitlet. Begrunnelsen for å kalle slike fødsler avvikende er at disse fødslene skal overvåkes. Logikken er tvilsom og klart uheldig.

Omfattende tabeller over fødselsvarighet basert på materialer fra 1970-årene er av historisk interesse i dag. Det kan neppe være tvil om at oppfatningene av hvor lenge kvinner bør være i fødsel før man griper inn, er endret på 40 år. Avsnittet om partogram er illustrert med et bilde av Bergsjøs partogram fra 1970-årene, som i dag er historie og ikke i bruk lenger.

Omtalen av sfinkterskader og oppfølgingen etter slike skader er svært kortfattet. Sekvele etter sfinkterskader utgjør et stort og skjult kvinnehelseproblem som vordende leger bør ha mer kunnskap om enn det de får her.

I kapitlet om spontanabort omtales blødninger i tidlig svangerskap som «truende abort». Dette begrepet oppsto den gang man ikke kunne avgjøre om fosteret levde og bare måtte vente og se. Oppdaterte studenter vet nå at ved førstetrimesters blødning tar man ultralyd. Dersom svangerskapet er intakt, er regelen at prognosen er god, tross blødning, og spontanabort truer ikke. Blødninger i tidlig svangerskap bør derfor omtales som nettopp det.

Moderne er det derimot å omtale gravide kvinner som moren (et kapittel heter Sykdommer hos moren). Regelen om at man blir mor først når man har født et barn, gjelder fortsatt.

Bekkenløsning er omtalt på få linjer. Mer moderne terminologi er bekkenleddsyndrom. Alene hyppigheten av denne tilstanden gjør at studentene bør forberedes grundigere, både om diagnostikk og aktuelle differensialdiagnoser og kunnskapsbasert behandling.

Kapitlet om gynekologisk undersøkelse er omfattende og svært teknisk preget. Det står for eksempel at legen ofte har behov for en hjelpende hånd. Det burde stått at en lege aldri bør være alene i en undersøkelsessituasjon, men alltid ha med en sykepleier eller legesekretær, uavhengig av pasientens lovfestede rett til å ha med en person.

Oppsummert kan jeg si at dette læreverket er sterkt preget av at det ble til i 1980-årene. Etter min vurdering er denne utgaven mer ujevn enn den forrige, fordi forskjellen mellom de gode kapitlene og kapitlene som burde vært grundig revidert, er blitt større. En strengere redaksjonell bearbeiding hadde vært tjenlig. Forfatterne burde systematisk skissert oppgavefordelingen mellom primærhelsetjeneste og spesialisthelsetjeneste. Vordende leger burde finne klare svar på hva som forventes av en lege i allmennpraksis, og når det er grunn til henvisning. Viktige temaer burde vært styrket, og prinsippet om kunnskapsbasert medisin burde vært førende.

\section{Bjørn Backe}

Dr.med., Trondheim 